\title{
耐熱チタン合金Ti-6242Sの高温特性に及ぼすミクロ組織の影響
}

鈴木昭弘 $^{* 1}$, 野田俊治 ${ }^{*} 1$, 岡部道生 ${ }^{* 2}$

\section{Effect of Microstructures on Mechanical Properties of a Heat Resistant Titanium Alloy Ti-6242S at Elevated Temperatures}

\author{
Akihiro Suzuki, Toshiharu Noda, and Michio Okabe
}

\section{Synopsis}

The weight reduction has been vital to improve the performance of automobile engines for moving components such as intake and exhaust valves, valve springs and connecting rods. Titanium alloys are one of the candidate light weight materials for them. Among them a near alpha Ti-6242S (Ti-6Al-2Sn-4Zr-2Mo-0.1Si) is a promising heat resistant alloy, which is applied to compressor discs of jet engines. Their maximum operating temperature has been limited to $873 \mathrm{~K}$ and so there are quite few data on its mechanical properties over it. In order to apply Ti-6242S to exhaust valves, its microstructure was optimized to obtain the fatigue and creep strength required up to $1073 \mathrm{~K}$.

The 19mm round bars in three typical microstructures, equiaxed, bi-modal and acicular, were prepared through thermomechanical processing. Their tensile, fatigue and creep properties were evaluated from room temperature to $1123 \mathrm{~K}$. The acicular material exhibited the best combination of all properties, which is most applicable to exhaust valves exposed to $1073 \mathrm{~K}$. The equiaxed one with the highest fatigue strength at room temperature showed the lowest mechanical strength at 1073K. The bi-modal material possessed just the intermediate strength between the acicular and the eqiaxed ones.

\section{1. 緒 言}

チタン合金は鋼に比べ比強度 (引張強さ/密度) に優れ るといった特長を有しており これまで航空機用途を中心 に合金開発がなされてきた .しかし最近ではコンロッド 1)，吸排気バルブ 2,3),バルブリテーナ ${ }^{4)}$ 等の自動車エンジ ン部材, ゴルフクラブ5), メガネフレーム ${ }^{6)}$ など航空機産 業以外の各種民生品へも広がりをみせている．とくに自動 車エンジン用排気バルブでは局部的に $973 \mathrm{~K}$ 以上の高温に 曝されるような部位が生じるため2), 兴の耐熱性向上に対 するニーズは益々高くなる一方である .

Ti-6Al-2Sn-4Zr-2Mo-0.1Si 合金 (以下 Ti-6242S と称す) は，a 安定化元素である $\mathrm{Al}$ を 6mass\%含有し , クリープ 特性を向上させるべく Sn と Zr, Si を適量添加，また，引 張特性, 疲れ特性を向上させるべく $\beta$ 安定化元素の Mo を $2 \%$ 添加した near a 型のチタン合金である .この合金 はクリープ特性と疲れ特性のバランスに優れ，1970 年代
前半に米国で工業化されて以来 ${ }^{7)}$, 現在でも航空機エンジ ンのコンプレッサーディスク等に使用される最も代表的 な耐熱チタン合金である .S.Ankem ら ${ }^{8)}$ (同合金のクリー プ特性に及ぼす Fe の影響を調査し，0.24 から 0.02 mass \% まで低下させることで , 783K , 242MPa における最小ク リープ速度を $1 / 3$ 以下に向上できることを示した . また， S.Amkem ら ${ }^{8)}$ および P.J.Bania ら ${ }^{9)}$ は ,783K でのクリープ 特性に及ぼす固溶化熱処理条件の影響を調査し， $\beta$ トラ ンザス直上で固溶化処理した針状組織材は, $(\alpha+\beta)$ 域で 固溶化処理した Bi-modal 組織 (混合組織) 材より良好な クリープ特性が得られることを示した.一方, 疲れ特性 は, 針状組織材より，等軸 a を含む混合組織材が良好と なることが知られており 7), 同合金においては通常 $\beta$ 卜 ランザス直下での 1228 から $1253 \mathrm{~K}$ での固溶化処理と 813 から $868 \mathrm{~K}$ での時効処理を組合わせることが一般的である 10). しかし，これらの評価はいずれも $873 \mathrm{~K}$ 以下での検討 であり，873K を越えるような高温域で機械的性質を評価 
した報告は見当たらない．

そこで本研究では，この Ti-6242S 合金を自動車エンジ ン用排気バルブへ適用するにあたり，873K を越える温度 域での機械的性質に及ぼすミクロ組織の影響を調査し， 873K を越える高温における適正ミクロ組織を検討した。

\section{2. 実験方法}

供試材の化学成分および $\beta$ トランザスを Table 1 に示 す . 微量元素として $\mathrm{Fe}$ を $0.03 \%, \mathrm{O}$ を $0.11 \%$ 含有する Ti$6242 \mathrm{~S}$ 合金であり 本合金の $\beta$ トランザスは $1268 \mathrm{~K}$ である .

一次溶解をプラズマ積層凝固炉 ${ }^{11)}$ において，二次溶解 を真空アーク溶解炉において実施し, 直径 $240 \mathrm{~mm}$, 重量

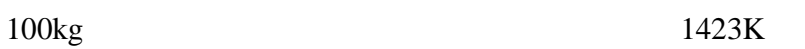
第 1 次の分塊鍛造を，次いで $1223 \mathrm{~K} の(\alpha+\beta)$ 域で第 2 次の分塊鍛造を実施し，直径80mmのビレットを製造した．

このビレットを用いて Table 2 に示す 3 種類のミクロ組 織が得られる条件で供試材を製造した．すなわち第 1 の製 造法については等軸状組織を得るためのものであり，ビ レットを $\beta$ トランザス (1268K) 以下の $1223 \mathrm{~K}$ に加熱， $(\alpha+\beta)$ 域圧延し直径 $19 \mathrm{~mm}$ の棒材を製造，次いで $1073 \mathrm{~K}$ で 10.8ks の焼なましを実施した . 第 2 の製造法は混合組 織を得るためのものであり，1223K での $(\alpha+\beta)$ 域で $19 \mathrm{~mm}$ の棒材を圧延した後, $1243 \mathrm{~K}$ で $3.6 \mathrm{ks}$ の加熱保持し 空冷する $\beta$ トランザス直下での固溶化処理を実施した . この製造法のものも，等軸状組織材と同樣の $1073 \mathrm{~K}$ で $10.8 \mathrm{ks}$ の焼なましを実施した．通常固溶化処理後に実施す る焼なまし温度としては高いが, 873K 以上の高温特性を 評価することを考慮し，焼なましとして 1073K を選定し た.第 3 の製造法は針状組織を得ようとするためのもので あり，ビレットを $\beta$ トランザス以上の $1323 \mathrm{~K}$ に加熱，鍛 造により直径 $19 \mathrm{~mm}$ の棒材を製造した . 熱処理としては， 他のものと同樣に 1073K，10.8ks の焼なましを実施した .
こうして得られた 3 水準の供試材に対し，等軸状組織， 混合組織並びに針状組織となっていることを確認し, 各種 機械的性質の調査を実施した，機械的性質は，常温から 1123K までの高温引張特性, 873 から 1023K でのクリープ 特性, さらには常温から $1123 \mathrm{~K}$ までの回転曲げ疲れ特性 を調査した.引張試験片およびクリープ試験片は平行部直 径 $6 \mathrm{~mm}$, 標点間距離 $30 \mathrm{~mm}$ とした . また引張強さの測定 は $0.15 \% / \mathrm{sec}$ の試験速度で実施した . 疲れ試験片は平行部 径 $8 \mathrm{~mm}$ の試験片とした . また, 回転曲げ疲れ試験時の繰 返し負荷速度は $58 \mathrm{~Hz}$ とした。

\section{3.結果および考察}

\section{1 ミクロ組織}

供試材のミクロ組織をFig.1 に示す.第 1 の製造法であ る $(\alpha+\beta)$ 域圧延+焼なましにより製造した供試材は， 約 $3 \mu \mathrm{m}$ の粒状 $\alpha$ 相を主体とし一部粒界部に微細な $\beta$ 相 を含有する等軸状組織である 第2の製造法である $(\alpha+\beta)$ 域圧延 + 固溶化 + 焼なましにより製造した供試材は，約 $6 \mu \mathrm{m}$ の等軸 $a$ 相と針状 $\alpha$ 並びに粒界 $\beta$ 相からなってい る混合組織を有している．また第 3 の製造法である $\beta$ 域 成形+焼なましにより製造した供試材は,約 $170 \mu \mathrm{m}$ の粗 大な旧 $\beta$ 粒内に針状 $\alpha$ が全面に形成された針状組織であ る.いずれも，代表的な等軸状組織，混合組織，針状組織 であり，これらを用い，各種機械的性質を調査した。

\section{2 引張特性}

高温引張特性を Fig.2 に示す．等軸状組織材，混合組織 材, 針状組織材の常温引張強さは, 光れ光れ 1006,967 並 びに 1044MPa であり, 針状組織材がもっとも高強度で, 等軸状組織材が光れに続き混合組織材がもっとも低くな る.試験温度が上がっても針状組織材がもっとも高強度レ ベルを維持する傾向は変化しないが,等軸状組織材と混合 組織材の順位は入れ替り $873 \mathrm{~K}$ 以上では等軸状組織材の引

Table 1. Chemical composition (mass\%) and beta transus of specimen.

\begin{tabular}{c|c|c|c|c|c|c|c|c|c|c}
\hline Alloy & $\mathrm{Ti}$ & $\mathrm{Al}$ & $\mathrm{Sn}$ & $\mathrm{Zr}$ & $\mathrm{Mo}$ & $\mathrm{Si}$ & $\mathrm{O}$ & $\mathrm{N}$ & Fe & $\beta$ Transus \\
\hline Ti-6242S & Bal. & 6.0 & 1.9 & 3.9 & 2.0 & 0.09 & 0.11 & 0.01 & 0.03 & $1268 \mathrm{~K}$ \\
\hline
\end{tabular}

Table 2. Finish hot working and heat treatment conditions of specimens.

\begin{tabular}{c|c|c|c}
\hline No. & Microstructure & Finish hot working & Heat treatment \\
\hline 1 & Equiaxed & $(\alpha+\beta)$ rolling $: 1223 \mathrm{~K}$ & $1073 \mathrm{~K} / 10.8 \mathrm{ks} / \mathrm{AC}$ \\
\hline 2 & Bi-modal & $(\alpha+\beta)$ rolling $: 1223 \mathrm{~K}$ & $1243 \mathrm{~K} / 3.6 \mathrm{ks} / \mathrm{AC}+1073 \mathrm{~K} / 10.8 \mathrm{ks} / \mathrm{AC}$ \\
\hline 3 & Acicular & $\beta$-forging $: 1323 \mathrm{~K}$ & $1073 \mathrm{~K} / 10.8 \mathrm{ks} / \mathrm{AC}$ \\
\hline
\end{tabular}




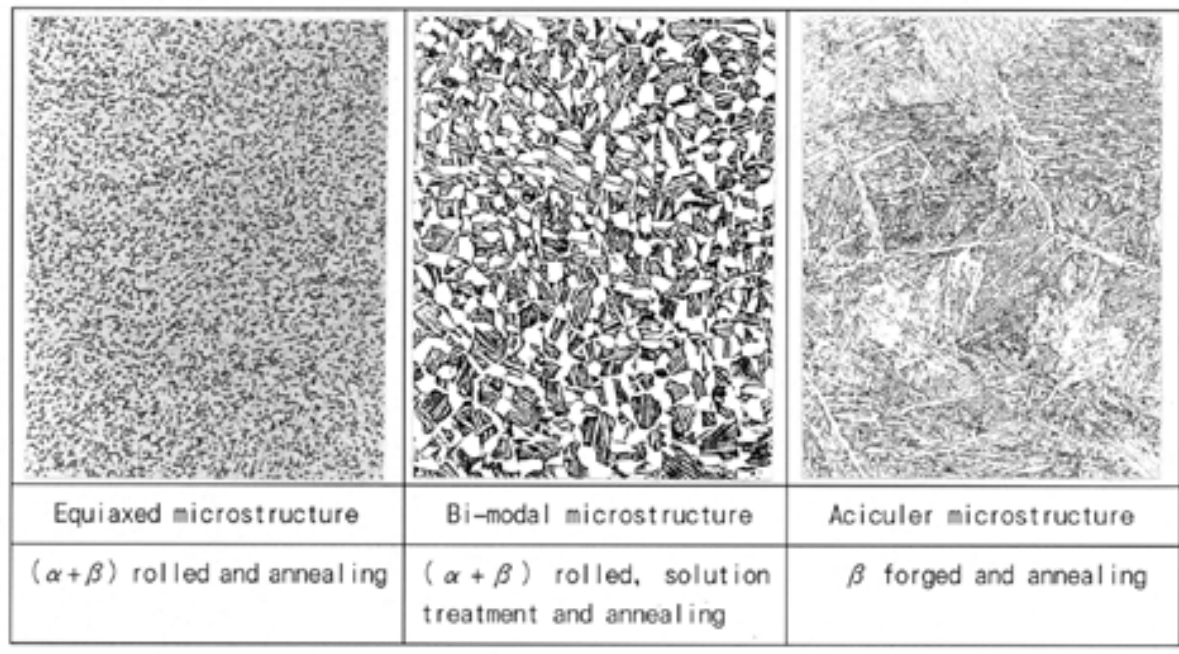

$50 \mu \mathrm{m}$

Fig.1. Microstructures of specimens.

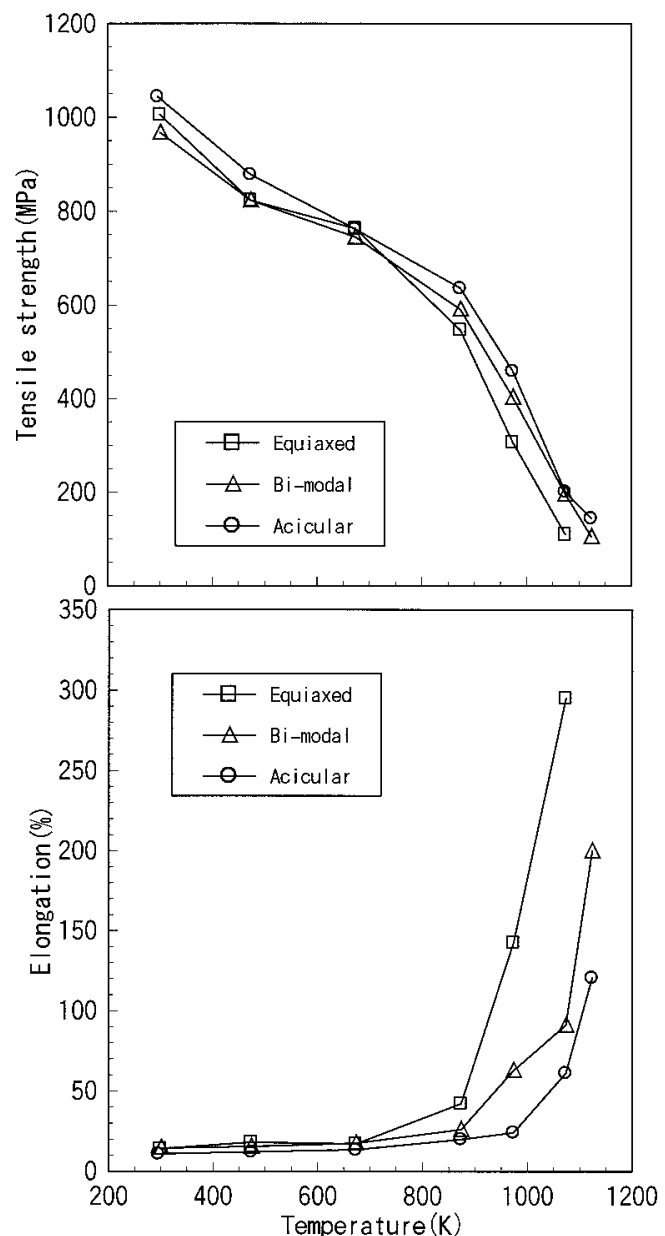

Fig.2. Effect of microstructures on tensile properties at elevated temperatures.

張強さがもっとも低くなる.とくに1073Kにおいては，等 軸状組織材では $110 \mathrm{MPa}$ 程度の引張強さしか得られないの
に対し，針状組織材では 200MPa 程度で倍近い強さレベル となる。

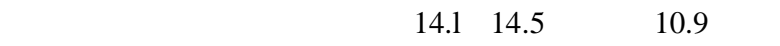
あり等軸状組織材および混合組織材に比へ, 針状組織材で は伸びが低めとなる.高温伸びは $673 \mathrm{~K}$ までは室温伸びと ほぼ同程度の値であるが，673K を越えると増加するよう になる・とくに等軸状組織材では $1073 K$ でも $295 \%$ ，混合 組織材でも $1123 \mathrm{~K} て ゙ 200 \%$ を有するようになる .

常温および 1073K 引張試験後の破面近傍の断面ミクロ 組織をFig.3に示す 等軸状組織材の常温引張試験片では, わずかではあるが破面近傍にもボイドが確認され，粒状 $\alpha$ 間もしくは粒状 a と粒界 $\beta$ の間でボイドの形成が確 認できる．一方針状 a を有する混合組織材および針状組 織材では内部にほとんどボイドが確認されない、針状組織 材の破面は, 針状 a 間もしくは針状 a と粒界 $\beta$ の界面 で破壊しており，混合組織材では等軸 $a$ と針状 $a$ もしく は粒界 $\beta$ の界面て破壞が生じている．1073K の引張試験 では,いずれも内部にボイドを形成する延性破壞となって いる。

従来，等軸状組織あるいは混合組織を有する Ti-6Al-4V 等の $(\alpha+\beta) 2$ 相合金においては $(\beta$ トランザス - $(50$ 〜 200) ) $\mathrm{K}$ 程度の温度域において低応力下でも粒界すべ りを伴う超塑性変形を生じる ${ }^{12)} こ と か ゙$ 知られており，本 合金でも細粒 a 相を有する 1073K 等軸状組織材では 295 \%の伸びを有し,粒界すべりによる超塑性変形が出現して いるものと推定される.一方, 粗大 $\beta$ 粒を有する針状組 織材においては, 超塑性変形が生じないことから，1073K 以上でも等軸状組織材に比べ高強度が得られたものと考 えられる。 


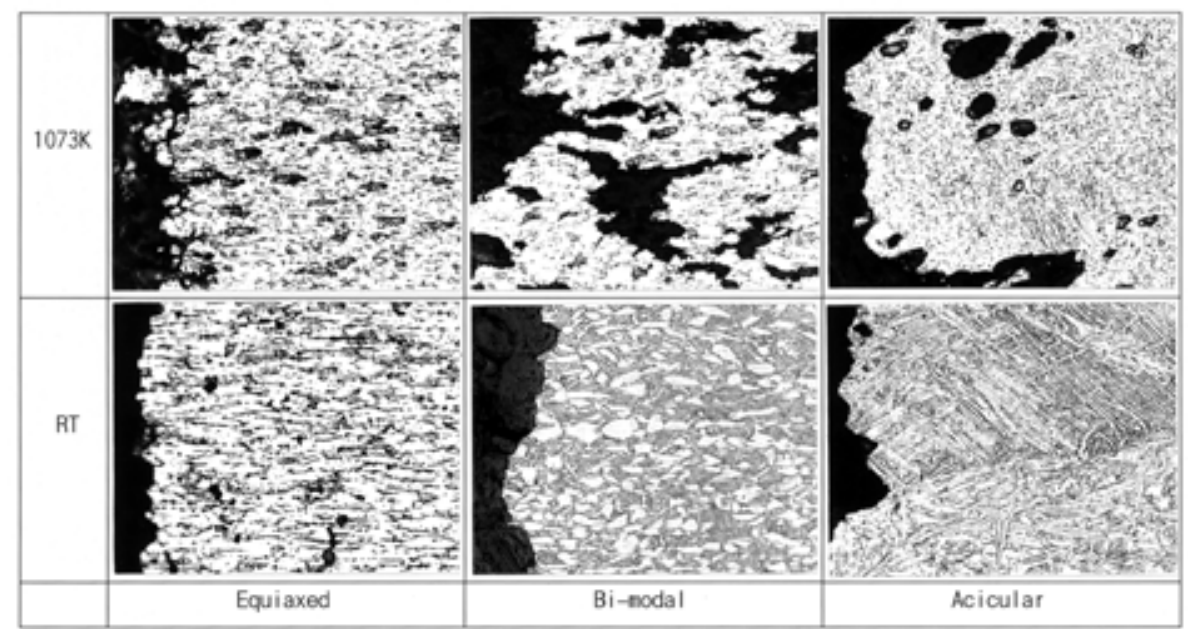

Fig.3. Cross-sectional microstructures after tensile test at room temperature and 1073K.

\section{3 クリープ特性}

1073K，39MPa の試験条件でのクリープ曲線を Fig.4 に 示す . 等軸状組織材は他のものに比べ $2 \%$ と初期伸びが大 きく,3.6ks 以下の短時間で $20 \%$ \%リープ伸びに達して いる．－一方針状組織材の初期伸びは等軸状組織材の $1 / 20$ 以下であり，また $20 \%$ までのクリープ伸びに達するのも $1.08 \mathrm{Ms}$ 以上で, 大幅にクリープ特性が改善される . 混合 組織材は，20\%のクリープ伸びに達するのに $46.8 \mathrm{ks}$ であ り，等軸状組織材と針状組織材の中間に位置する。

873 〜 1073K の試験温度での $1 \%$ \%リープ寿命をラーソ ン・ミラー・パラメータで整理した結果を Fig.5 に示す。 $1 \%$ クリープ寿命は粗大 $\beta$ 粒，粗大針状 $\alpha$ を有する針状 組織材がもつとも良好であり，ついで昆合組織材が, 細粒 a を有する等軸状組織材がもっとも低くなる .これらの 結果は,従来の $873 \mathrm{~K}$ 以下での評価結果 ${ }^{8,9)}$ と同樣である.

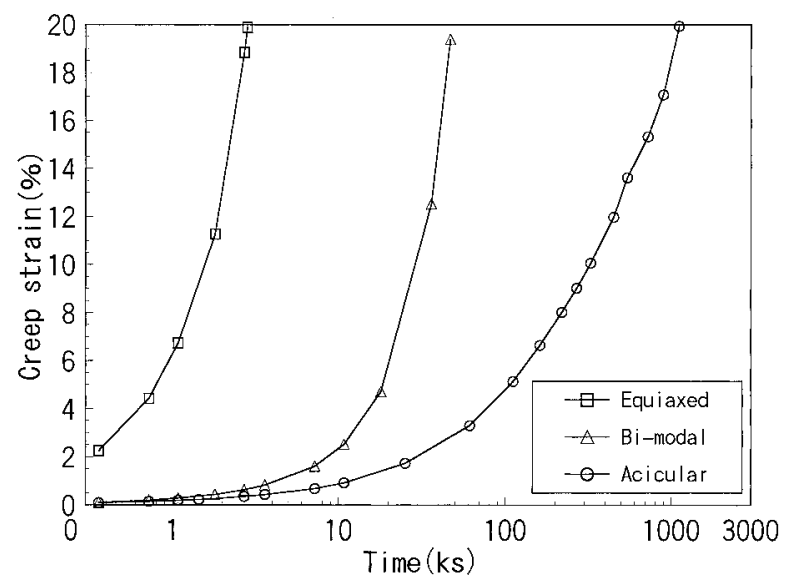

Fig.4. Creep curves at 1073K under 39MPa.

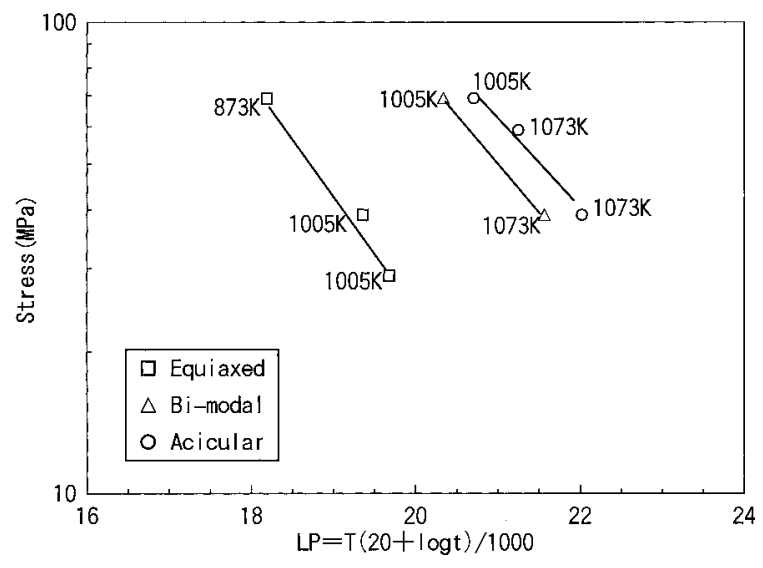

Fig.5. Effect of microstructures on $1 \%$ creep lives.

\section{4 回転曲げ疲れ特性}

$10^{7}$ 回回転曲げ疲れ限度に及ぼす試験温度の影響をFig.6 に示す.室温における等軸状組織材, 混合組織材, 針状組

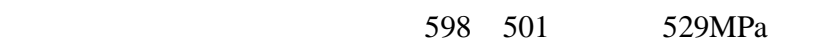
あり，等軸状組織材がもっとも良好である.しかし，873K ではいずれも約350MPaとなりミク口組織の影響は認めら れなくなる.さら 1073K になると，針状組織材の疲れ限 度が最も高くなり，等軸状組織材の疲れ限度の 2 倍近い値 となる。

代表的な疲れ破面をFig.7 に示す.常温疲れ破面はいず れも負荷のもつとも高くなる最表層部の1点を起点として いる.1073K 材でもやはり最表層部を起点とした破壊形態 ではあるが, 最表層部の酸化の影響を受け, 起点を 1 点に 限定することはできなくなる .

引張強さと $10^{7}$ 回回転曲げ疲れ限度の関係を一括して Fig.8に示す 常温における $10^{7}$ 回回転曲げ疲れ限度 $(\sigma \mathrm{wb})$ 


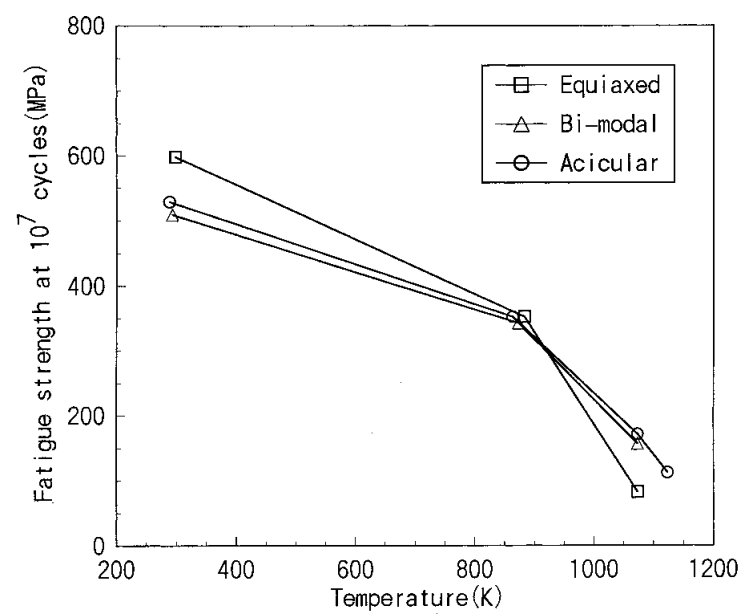

Fig.6. Effect of microstructure on rotating bending fatigue strength at $10^{7}$ cycles at elevated temperatures.

と引張強さ $(\sigma \mathrm{B})$ の比 (疲れ限度比 $\sigma \mathrm{wb} / \sigma \mathrm{B})$ は, 針状 組織材，混合組織材が約 0.5 であるのに対し，等軸状組織 材では 0.6 程度が得られもつとも良好である.等軸状組織 材は亀裂の発生抵抗に優れており，乥れが等軸状組織材の 常温疲れ限度が良好な要因と考えられている.一方 $887 \mathrm{~K}$ 以上の高温では, 従来の知見とは異なり，針状組織材が もっとも良好な疲れ限度を示すが,兰れは高い引張強さを 有しているためと考えられる．また，常温および873Kに 比べ, 1073K および 1123K においては高い疲れ限度比 ( $\sigma \mathrm{wb} / \sigma \mathrm{B})$ を有するようになる .1073K の疲れ試験材に は表層部に酸化によるа ケースか確認されており(Fig.9)， 疲れ試験中に最も負荷の加わる表層に酸素が濃化し固溶 強化を生じていることを示唆している，a ケースは常温 では延性がなく亀裂発生起点となりやすいため疲れ限度 を低下させるが ,1073K のような高温では延性を有するよ うになるため回転曲げ疲れ限度を高める要因となってい る可能性がある .

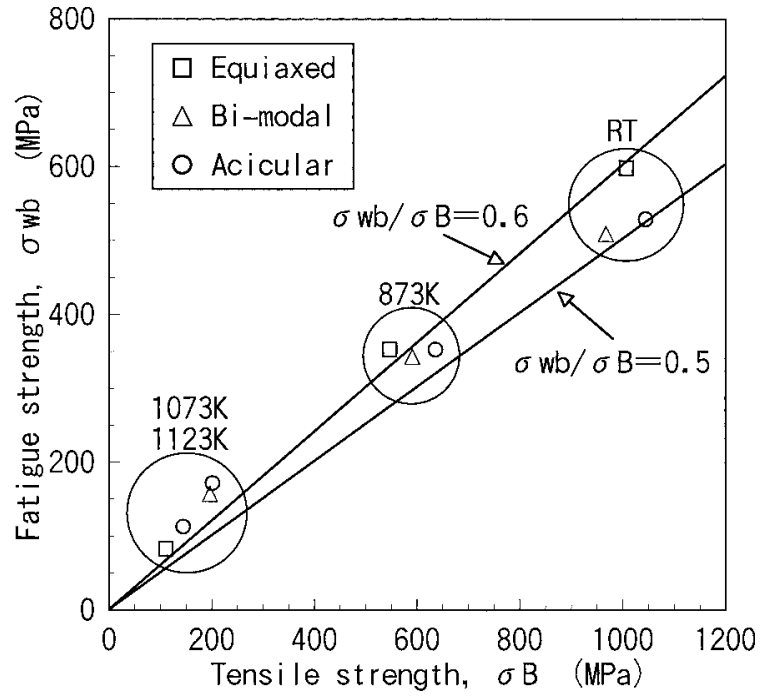

Fig.8. Tensile strength and rotating bending fatigue strength at $10^{7}$ cycles.

\section{4 . 排気バルブ材への適用}

以上の結果, 常温においては従来の報告通り，等軸状組 織材が良好な疲机特性を示した。しかし，873K 以上の高 温では,等軸状組織もしくは混合組織材より,針状組織材 のほうが,クリープ特性のみならず疲れ特性にも優れるこ とが明らかとなった．乥こで同合金排気バルブ材の開発に 際しては,もつとも温度の上がる傘部にミクロ組織制御に よって針状組織を適用した ${ }^{13)}$ 。

\section{5 . 結 論}

等軸状組織, 混合 (Bi-modal) 組織, 針状組織を有する Ti-6Al-2Sn-4Zr-2Mo-0.1Si 合金について, 1123K までの高 温での機械的性質に及ぼすミク口組織の影響を調査した . 弚の結果以下のことが明らかとなった .

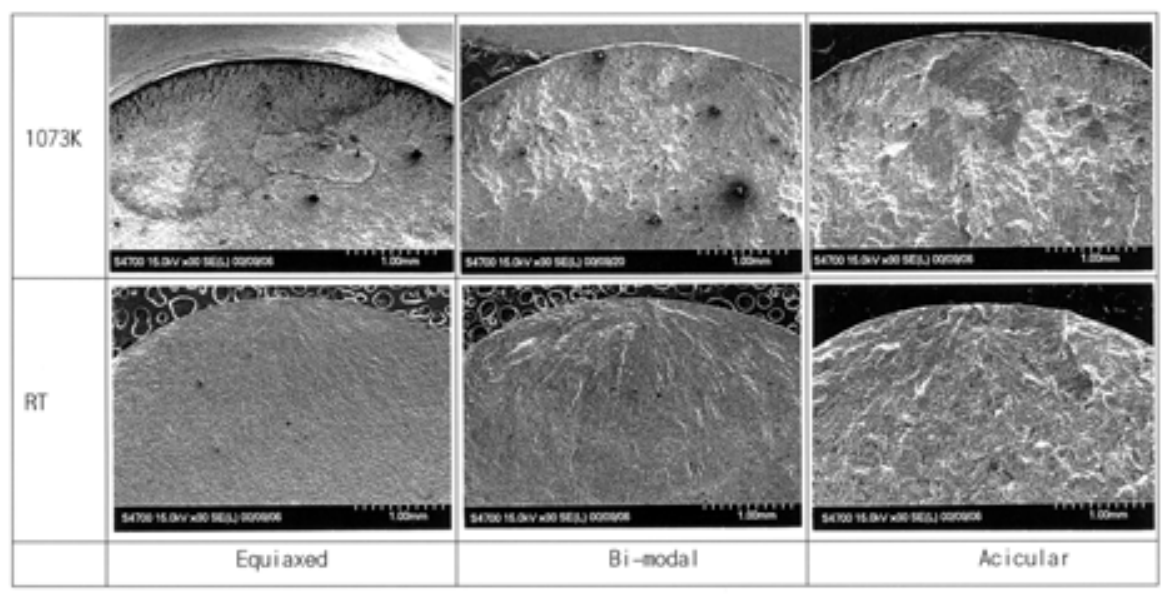

Fig.7. SEM fractgraphs after rotating bending fatigue test at room temperature and 1073K. 


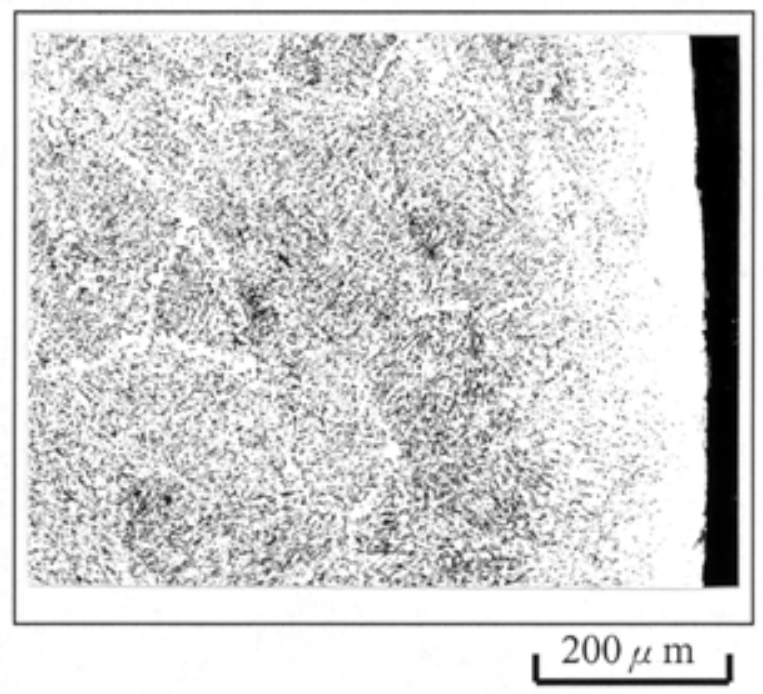

Fig.9. Cross-sectional microstructure of acicular specimen after rotating bending fatigue test at $1073 \mathrm{~K}$ under $177 \mathrm{MPa}$.

(1) 常温においては，等軸状組織材がもつとも良好な疲れ 特性を有していた．しかし，873K 以上の高温では，等軸 状組織材の疲れ限度は他の混合組織材, 針状組織材に比べ もっとも低くなった .

(2) 混合組織材の機械的性質は，等軸状組織材，針状組織 材の中間に位置する .

(3) $873 \mathrm{~K}$ 以上の高温域においては,クリープ特性のみなら ず疲れ特性も針状組織材がもっとも良好であった この結 果をもとに，自動車エンジン用排気バルブの傘部に針状組 織を適用した ${ }^{13)}$.

\section{謝 辞}

Ti-6242S バルブの開発・実用化は, 日産自動車株式会社 殿 ,フジオーゼックス株式会社殿の協力を得て行ったもの であり，ここに謝意を表します．

\section{(文 献)}

1)松原敏彦:チタニウム・ジルコニウム ,39)1991), 175.

2) 岡田義夫, 眞木邦雄, 安保定幸, 広瀬正仁, 浅沼宏昭: 鋳造 工学,73(2001), 12,818.

3 )斎藤卓:チタン ,48(2000) ,2,97.

4)M. Mushiaki et al.: SAE Technical Paper 910428.

5)寺西幸弘:設計工学 ,31(1996) ,5 165.

6) Y.Ohtakara et al. : Titanium 1986 Products and Applications Proceedings of the Technical Program from the 1986 International Conference 2) (1986),748.

7)草道英武ら (編集):金属チタンと炎の応用,日刊工業新
聞社 , , 1983) , 121.

$8)$ S.Ankem et al:Proceedings of the fifth world conference on titanium, (1984), 2411.

9)P.J.Bania and J.A.Hall:Proceedings of the fifth world conference on titanium, (1984), 2371.

10)R.Boyer et al.(Edited) : Materials Properties Handbook Titanium Alloy, ASM international, (1994), 374.

11)加藤剛志:チタニウム・ジルコニウム ,32(1984) 2, 96.

12)西野良夫 木村敏郎: 塑性と加工，27(1986) 302,339.

13 )毛利彰良, 廣瀬正仁, 浅沼宏昭, 岡部道生, 野田俊治 鈴 木昭弘:チタン ,50(2002), 1, 45. 